Pamiętnik Literacki 2019, 4, s. 161-171

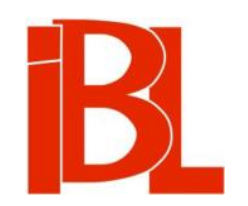

\title{
“Jeszcze". Jeszcze jeden przypis do wiersza Wisławy Szymborskiej
}

Katarzyna Kuczyńska-Koschany 
Pamiętnik Literacki CX, 2019, z. 4, PL ISSN 0031-0514

DOI: $10.18318 / \mathrm{pl} .2019 .4 .11$

KATARZYNA KUCZYŃSKA-KOSCHANY Uniwersytet im. Adama Mickiewicza, Poznań

\section{„JESZCZE” JESZCZE JEDEN PRZYPIS DO WIERSZA WISŁAWY SZYMBORSKIEJ}

Poetka dlatego właśnie mówi „nie wiem”, że wie zbyt wiele ${ }^{1}$.

Wiersz Wisławy Szymborskiej Jeszcze ukazał się najpierw w „Życiu Literackim” (1956, nr 51), przedrukowany został potem w tomie Wołanie do Yeti (1957) ${ }^{2}$, który twórczyni uznawała za swój właściwy debiut (czy też drugi debiut poodwilżowy); wreszcie pojawił się w autorskim, ponoblowskim wyborze poezji Widok z ziarnkiem piasku (1996) ${ }^{3}$. Gest Szymborskiej skomentował Michał Głowiński („Poetka włączyła wiersz ten do swojego kanonu”), badacz który poświęcił utworowi Jeszcze wiele uwagi ${ }^{5}$. Zinterpretował go w tomie zbiorowym, dedykowanym Marii Żmigrodzkiej (1998), następnie przedrukował ten sam esej w autorskim wyborze Monolog Telimeny $i$ inne szkice (2007), mówił także na jego temat podczas spotkania, zorganizowanego 7 III 2012, przez Pracownię Pytań Granicznych na Uniwersytecie im. Adama Mickiewicza w Poznaniu, jako o jednym $z$ trzech wielkich ${ }^{6}$ polskich

1 M. Głowiński, Wisławy Szymborskiej ballada o Zagładzie. W: Monolog wewnętrzny Telimeny i inne szkice. Kraków 2007, s. 351. Pierwodruk w zb.: Lustra historii. Rozprawy i eseje ofiarowane Profesor Marii Żmigrodzkiej z okazji pięćdziesięciolecia pracy naukowej. Red. M. Kalin ow s ka, E. Kiśla k. Warszawa 1998.

2 W. Szy m bor s ka, Wołanie do Yeti. Kraków 1957, s. 37-38. We wznawianej przez wydawnictwo „Znak” edycji wszystkich tomów dzieł noblistki zob. W. Szy mborska, Wołanie do Yeti. Kraków 2017.

3 W. Szy mbor ska, Widok z ziarnkiem piasku. 102 wiersze. Poznań 1996.

4 Głowiń ski, op. cit., s. 346, przypis 2. Niedawno wiersz trafił do kanonu poezji polskiej, znalazł się bowiem w wydaniu wyboru wierszy W. S zy m b o r s ki ej w serii „Biblioteki Narodowej” (Wybór poezji. Wstęp, oprac. W. Lig ęza. Wrocław 2016, s. 61. BN I 327).

5 Osobne interpretacje wiersza Jeszcze, późniejsze od tej Głowińskiego, zaproponowali T. C i eśla k (Opowieść o Holokauście. „Jeszcze” Wisławy Szymborskiej. W zb.: Wisława Szymborska. Tradice současnost - recepce. Materiály z mezinárodní vědecké konference uskutečněné v Ostravě ve dnech 4-5 prosince 2003 u př́ležitosti 80. narozenin Wisławy Szymborské. Red. M. B a l o w s k i, J. Ra clav s ká. Ostrava 2004) i pisząca te słowa (K. K u c zyń s ka - K o s c h a ny, Trzy wiersze najważniejsze: Szymborska. W: „Vse poèty židy”. Antytotalitarne gesty poetyckie i kreacyjne wobec Zagłady oraz innych doświadczeń granicznych. Poznań 2013).

$6 \quad$ W tym miejscu chciałabym, przyjmując rozpoznanie Głowińskiego, nie zgodzić się ze zdawkowa wypowiedzią A. Le ge ży ń s ki ej (Petnia. Kilka uwag o poetyckiej antropologii Wisławy Szymborskiej. W zb.: Niepojęty przypadek. O poezji Wisławy Szymborskiej. Red. J. G rą d zi e l-W ój c i k, K. Ski b s ki. Kraków 2015, s. 17), iż w zestawieniu z K. K. Baczyńskim (Pokolenie), T. Borowskim (Pieśń) czy T. Różewiczem (Ocalony) - „Szymborska mówiła o tym wszystkim [tj. o okropnościach okupacji/Zagłady] mniej głośno i mniej dramatycznie, lecz wojenne obrazy także będą jeszcze po 
wierszy o Zagładzie Żydów (obok „Ballad i romansów” Władysława Broniewskiego z tomu Drzewo rozpaczajace 〈1945〉 i Campo di Fiori Czesława Miłosza z roku 1943).

Wśród wielu istotnych uwag interpretacyjnych Głowińskiego zaintrygowała mnie ta, pozornie błaha: „W szkicu tym posługuję się tekstem z tomu Wołanie do Yeti, Kraków 1957"7. Postanowiłam sprawdzić, czy Szymborska zmieniała, poprawiała tekst; ewentualnie - co raczej może być tylko domysłem - czy ingerowała cenzura. A także druga uwaga:

Zanim [...] podejmę trud interpretowania tego niezwykłego utworu, muszę przypomnieć wiersz o kilka lat wcześniejszy, który uległ niemal całkowitemu zapomnieniu, nigdy nie był przedrukowywany (wspomina o nim w swej książce Aneta Wiatr). Ogłoszony on został w roku 1948 i stanowi bezpośrednią zapowiedź ballady z tomu Wołanie do Yeti ${ }^{8}$.

\section{Mowa o wierszu Transport Żydów 1943.}

Najpierw jednak spróbuję przytoczyć najistotniejsze ustalenia czworga interpretatorów wiersza Jeszcze.

\section{Edward Balcerzan:}

Bezpośrednim impulsem do napisania tego tekstu stał się literacki koncept balladowego wiersza Wisławy Szymborskiej Jeszcze, który - tak jak wiele innych jej poetyckich kompozycji - polega na wielokrotnym wykorzystaniu tego samego chwytu. W świecie Jeszcze uwięzionych ludzi wszędzie czeka smierć: wewnątrz zaplombowanych wagonów, na torach, w czarnym lesie, pośród innych. Sytuacja jest czytelna, ale zakomunikowana zostaje nie wprost: „przesłonięta” przez ciąg antonomazji. Dramat osób, ich cierpienie, ich bunt, ich konanie stają się dramatem imion. Nie osłabia to, przeciwnie, potęguje grozę bezradności ${ }^{9}$.

\section{Wojciech Ligęza:}

W wierszu Jeszcze bolesne wspomnienie o holokauście konkretyzuje się w postaci podróży do miejsca zagłady, już nie ludzi, lecz ich imion. Te żydowskie imiona stają się źródłem zagrożenia, podobnie jak cechy antropologiczne. Szyderstwo dziejów spełnia się do końca. Podpowiedź, by w nieludzkich czasach, w niewłaściwym kraju uprawiać sztukę mimikry, ma wydźwięk tragiczny. Zbrodnicze praktyki odwracają cywilizowane pojęcia o sądzie i sądzeniu [...].

Liczenie i dzielenie ma tu wszelkie znamiona złowrogiego w swych skutkach absurdu. Taka wymierność służy systemowi zagłady, w którym najgroźniejsza jest perfidnie dobrana norma. Wtedy zło spełnia się niejako automatycznie. [...]

Tego rodzaju zachwianie wagi, przebranie miary - określające szaleństwo dziejów - przydarza się w skali masowej w każdym totalitaryzmie. Polega ono również na dopisywaniu szlachetnych słów do haniebnych czynów ${ }^{10}$.

wielu latach powracały w jej snach i wierszach (Sen, Jeszcze)". Nie można nazwać utworu Jeszcze czy wcześniejszego o dekadę Transportu Żydów wierszami, w których poetka mówi „mniej głośno i mniej dramatycznie”. Ściszenie głosu jest tu bardzo dramatyczne, cisza uderza w ciszę, łomoce, zaświadcza o bezradności osoby patrzacej na Zagładę i na brak reakcji otoczenia wobec niej (czy też wobec obronnej mimikry: imiona żydowskie, cała społeczność, jadą pociągami śmierci do obozów zagłady; by przetrwać w tym antysemickim kraju, by uniknąć pogromu czy akcji wagonowej po wojnie, trzeba się przystosować - dać dziecku słowiańskie imię, ukryć tożsamość). Głowiń s ki, op. cit., s. 346.

8 Ibidem, s. 346-347. O wierszu Transport Żydów 1943 pisze A. Wiatr (Syzyf poezji w piekle wspótczesności. Rzecz o Wisławie Szymborskiej. Warszawa 1996, s. 159).

9 E. Balc erza n, Synekdochy Wisławy Szymborskiej. W: Humanisto, kim jesteś? Kraków 2018, s. 351.

10 W. Ligęza, O poezji Wisławy Szymborskiej. Świat w stanie korekty. Kraków 2002, s. 322-323. 
W tomie Wołanie do Yeti wraz z przekraczaniem tabu politycznego następuje ośmielenie współczującej wyobraźni. Tak dzieje się w znakomitym wierszu Jeszcze, w którym rozwianie się w powietrzu ofiar Holokaustu („chmura ludzi nad krajem szła”) oraz zamilknięcie wołających o pomoc głosów nie tylko służy upamiętnieniu, ale też pośrednio oskarża zafałszowaną świadomość. Zamordowanym Żydom ofiarowano skąpo odmierzane współczucie lub obojętność. Warto zwrócić uwagę na oksymoroniczne zestawienie słów umieszczone poza (możliwym) komunikatem słownym „łomotanie ciszy w ciszę” - przypominające o tragedii wykluczonych. Szymborskiej „ballada o Zagładzie” wprowadza temat, o którym wówczas mówiło się zdecydowanie za mało ${ }^{11}$.

\section{Tomasz Cieślak:}

Wiersz to niezwykły, opowieść - dziwna. Oto bowiem, pisząc o Holokauście, poetka sięga z jednej strony, głęboko i kompetentnie, do źródeł biblijnych, a jednocześnie, $z$ drugiej - do popularnych wzorców, głównie zresztą rytmicznych, poezji dziecięcej, w tym zwłaszcza czytelnie do swoistej ikony poezji dziecięcej, jaką w 1957 roku, zaledwie cztery lata po śmierci Juliana Tuwima, była jego Lokomotywa. Dlatego niektóre zabiegi konstrukcyjne, obecne w wierszu Szymborskiej, są pośrednim nawiązaniem do Lokomotywy, opublikowanej na łamach „Wiadomości Literackich” dwadzieścia jeden lat przed Jeszcze; poetka prowadzi grę $\mathrm{z}$ modelem dziecięcego, optymistycznego wiersza przedwojennego ${ }^{12}$.

Formalne pokrewieństwo pomiędzy tak różnymi w istocie wierszami służy tym bardziej wyrazistemu wykreowaniu kontrastu: pomiędzy witalistyczną, radosną wizją świata [...], wizją zapisaną [...] czytelnie w międzywojennej Lokomotywie [...] - a krańcowym tragizmem wojennego doświadczenia: przerażenia, bezsilności, śmierci, jakie nastały w Europie zaledwie trzy czy cztery lata po opublikowaniu niezmąconej w swej radości Lokomotywy (pisanej, dodajmy, w okresie, gdy w lirycznej twórczości Tuwima dla dorosłych dominowały ciemne tony) ${ }^{13}$.

Trójdzielność wiersza, ze względu na usytuowanie podmiotu i układy rymowe wygląda [...] tak: opis wojennego transportu do obozu zagłady, wypełniający część pierwszą i nawiązujący makabrycznie do Lokomotywy Tuwima [...], rodzi [...] bardzo emocjonalną, związana z bezpośrednim zwróceniem się do ofiar, refleksję na temat antysemityzmu, nadal trwającego, po wojnie, w „tym kraju”, gdzie dokonał się Holokaust [...].

W trzeciej części następuje pozorne uspokojenie. [...] Przychodzi bardziej generalna myśl - o powszechnym zapomnieniu wojennych ofiar [...] oraz własnej - podmiotu mówiącego, wbrew temu ogólnemu zapomnieniu trwającej - pamięci o zamordowanym narodzie żydowskim, pamięci rodzącej nocne koszmary („Obudzona w nocy słyszę / [...] łomotanie ciszy w ciszę”, w. 28-29), co zostało wyrażone jedyna w tym wierszu strofą miarowego jedenastozgłoskowca.

Tak też, jako świadectwo pamięci, wbrew otoczeniu i pomimo mijającego czasu, interpretować należy tytuł wiersza: Jeszcze. Przeszłość jest oto trwałą częścią doświadczenia, rodzi aktualne refleksje, istnieje boleśnie w świadomości podmiotu mówiącego. Będąc historią - nadal budzi emocje, tragiczne fakty zdają się być wręcz składową krajobrazu (trwając w nim poprzez wrażenia słuchowe). Swoiście wyczulony, metaforycznie pojmowany słuch - skierowany ku przeszłości - zdaje się być przy tym podobny do zapisu bieżącego trwania przeszłości wykreowanego przez Krzysztofa Kamila Baczyńskiego w wojennym wierszu Historia, napisanym w 1942 roku, a zakończonym frazą: „Jeszcze słychać śpiew i rżenie koni”14.

W. Lig ęza, wstęp w: Szy mbors ka, Wybór poezji, s. LXIV. Warto przy tym zauważyć, że „łomotanie ciszy w ciszę" to również tautologia, nie tylko oksymoron; ponadto cisza straszliwie „łomocze”, „dudni”, kiedy odzyskuje się słuch fizycznie, a także metaforycznie (kiedy słyszy się mimo tych, którzy nie chcą słyszeć).

12 Ci eśla k, op. cit., s. 36. Badacz błyskotliwie porównał wiersz Szymborskiej z Lokomotywa J. Tuwima, wskazując „podobną organizację rymową nierównozgłoskowców” (s. 37) i rozbicie tego ładu u poetki, anafory itd., powtórzenie charakterystycznych fraz. Odniósł się polemicznie do interpretacji Ligęzy - tłumacząc m.in., dlaczego autorka Jeszcze wymieniła te, a nie inne imiona żydowskie. Nawiązał też do zagładowego toposu „pociągów śmierci” - „bydlęcych wagonów”. 


\section{Anna Zarzycka:}

Zarówno Głowiński, jak i Cieślak interpretują wiersz Jeszcze przede wszystkim jako wiersz o Zagładzie. Zaproponowane przeze mnie odczytanie sytuuje natomiast utwór Szymborskiej w kontekście całego tomu Wołanie do Yeti, w porządku diachronicznym, historycznoliterackim, to znaczy jako wyraz świadomości historycznej poetki - świadomości nowo zdobytej czy też nowo odkrytej, co oznacza, że również szczególne czułej i skrupulatnej (stąd mowa tu o „poczuciu etycznego zobowiązania”). Oczywiście, oba kierunki odczytań nie wykluczają się, lecz wzajemnie dopełniają ${ }^{15}$.

\section{Warianty $^{16}$}

\section{1: 1956, pierwodruk czasopiśmienny $=1957$, druk $\mathrm{w}$ tomie}

W zaplombowanych wagonach jada krajem imiona, a dokąd tak jechać będą, a czy kiedy wysięda nie pytajcie, nie powiem, nie wiem.

Imię Natan bije pięścią w ścianę, imię Izaak śpiewa obłąkane, imię Sara wody woła dla imienia Aaron, które umiera z pragnienia.

Nie skacz w biegu, imię Dawida. Tyś jest imię skazujące na klęskę, nie dawane nikomu, bez domu, do noszenia w tym kraju zbyt ciężkie.

Syn niech imię słowiańskie ma, bo tu liczą włosy na głowie, bo tu dzielą dobro od zła wedle imion i kroju powiek.

Nie skacz w biegu. Syn będzie Lech. Nie skacz w biegu. Jeszcze nie pora. Nie skacz. Noc się rozlega jak śmiech i przedrzeźnia kół stukanie na torach.

Chmura $z$ ludzi nad krajem szła, $z$ dużej chmury mały deszcz, jedna łza, mały deszcz, jedna łza, suchy czas. Tory wiodą w czarny las.

Tak to, tak, stuka koło. Las bez polan. Tak to, tak. Lasem jedzie transport wołań. Tak to, tak. Obudzona w nocy słyszę tak to, tak, łomotanie ciszy w ciszę.

A. Zarzycka, Rewolucja Szymborskiej 1945-1957. O wczesnej twórczości poetki na tle epoki. Poznań 2010, s. 245, przypis 442.

16 W wierszach Jeszcze i Transport Żydów zmiany w stosunku do wersji wcześniejszej wyróżnione zostały pogrubieniem (w wersji późniejszej). 
2: 1996, druk w tomie

W zaplombowanych wagonach

jadą krajem imiona,

a dokąd tak jechać będą,

a czy kiedy wysięda

nie pytajcie, nie powiem, nie wiem.

Imię Natan bije pięścią o ścianę,

imię Izaak śpiewa obłąkane,

imię Sara wody woła dla imienia

Aaron, które umiera z pragnienia.

Nie skacz w biegu, imię Dawida.

Tyś jest imię skazujące na klęskę,

nie dawane nikomu, bez domu,

do noszenia w tym kraju zbyt ciężkie.

Syn niech imię słowiańskie ma,

bo tu liczą włosy na głowie,

bo tu dzielą dobro od zła

wedle imion i kroju powiek.

Nie skacz w biegu. Syn będzie Lech.

Nie skacz w biegu. Jeszcze nie pora.

Nie skacz. Noc się rozlega jak śmiech

i przedrzeźnia kół stukanie na torach.

Chmura $z$ ludzi nad krajem szła,

z dużej chmury mały deszcz, jedna łza, mały deszcz, jedna łza, suchy czas.

Tory wiodą w czarny las.

Tak to, tak, stuka koło. Las bez polan.

Tak to, tak. Lasem jedzie transport wołań.

Tak to, tak. Obudzona w nocy słyszę

tak to, tak, łomotanie ciszy w ciszę.

\section{Analiza}

Utwór składa się z menorowych ${ }^{17} 7$ strof. Pierwsza - jakby wiersz dopiero nabierał rytmu - jest anakruzowo dłuższa, ma 5 wersów, podczas gdy pozostałe mają po 4 . W wierszu występują rymy, co u Szymborskiej nieczęste, a pierwsza osoba ujawniona zostaje tylko w ostatniej strofie, w wyraźnym odwołaniu do powidoku lub echa autobiograficznego. Dynamika wiersza wydaje się szczególna. Rozpoczyna się on od narracji w trzeciej osobie, jak w rymowanej historiografii (z aluzją do stylizacji biblijnej: „wysiędą) - w strofie pierwszej; przez lakoniczne (jak na nagrobku) opisanie losu poszczególnych osób-imion - w strofie drugiej; przez apostrofę: „Nie skacz w biegu”, zwrot proszalny, ocalający nieudolnie życie, skierowany do jedne-

17 Menora nawiązuje do 7 dni tygodnia jako konsekwencji 7 dni stworzenia. Widnieje w herbie państwa Izrael. Jej inspiracja jest szałwia judejska, roślina wedle tradycji żydowskiej zapewniająca nieśmiertelność. 
go imienia, paradygmatycznego dla całego narodu (Dawid) - w strofie trzeciej; zwrot ten powiązany jest $\mathrm{z}$ rozbudowaną diagnozą sytuacji Żydów w Polsce w czasie Zagłady i nieustannego zagrożenia życia, przedstawionych w strofie czwartej; aż po trzykrotną antysamobójczą anaforę: „Nie skacz w biegu” - w strofie piątej, spojoną z namowa do ukrycia prawdziwej tożsamości dla ochrony przed antysemityzmem (jak się zdaje, już nie tylko przed groźbą niemieckiej eksterminacji - wiersz powstał bowiem po pogromach krakowskim i kieleckim, po akcjach pociagowych), z namową do kamuflażu („Syn będzie Lech”). W strofie szóstej, przedostatniej, rysuje się bezradność i brak empatii ze strony polskich współobywateli po akcie eksterminacji Żydów ${ }^{18}$, strofa finalna zaś zdaje się (podobnie jak wiele innych wierszy o Zagładzie) zainspirowana - przede wszystkim pod względem rytmiki - Lokomotywa Tuwima (myślę o potrojonej anaforze „Tak to, tak”).

Warto zwrócić uwagę na rytm w całym wierszu (naśladujący stukot kół) oraz szczególną dynamikę rymów i anafor. W pierwszej strofie, 5-wersowej występują rymy styczne $a a b b x$, żeńskie, dokładne, druga para rymowa wzmocniona anafora „a”, z pozornie nierymowaną kodą $\mathrm{w}$ wersie piątym (w rzeczywistości pojawia się tam rym męski wewnętrzny: „nie powiem, nie wiem” - tautologiczny). Układ rymów jest tu bardzo ciekawy - sfeminizowanemu ${ }^{19}$ tłokowi wewnatrz pociagów śmierci (cztery pierwsze wersy) towarzyszą rymy w polszczyźnie częstsze, „normalne”, a samotny, wewnętrzny rym męski przypomina niemieckiego strażnika albo/i polskiego kolejarza (takiego jak w filmie Shoah Claude'a Lanzmanna), kierującego lokomotywą, od której odczepia się wagony. Jeszcze intensywniej działa na czytelnika (a zwłaszcza na słuchacza) układ rymów wespół z ich semantyką: „wagonach” „imionach” (głęboki rym i takież znaczenie znoszenia, anihilacji imion - domyślnych osób, zredukowanych w tych pociagach do przeznaczonych na pewną, zadekretowana śmierć); „będa” - „wysięda” ( $z$ sugestią podwyższenia tonacji przez inwersję ,jechać będą" oraz formę archaiczna). W piątym wersie wracają mowa teraźniejsza i neutralność stylistyczna, narzucona, w sposób nieubłagany, przez tautologię.

Kolejne strofy sa konsekwentnie 4-wersowe i rymowane według pewnego, chciałoby się rzec: symetrycznego, wzorca. W strofie drugiej, enumeracyjnej - ccdd (rymy styczne, żeńskie, dokładne: „ściane” - obłąkane”; „imienia” - „pragnienia”, z brzmieniem koherentnym wobec znaczenia zamknięcia / uwięzienia / sytuacji bez wyjścia i powolnego konania osoby pozbawionej wody). W strofie trzeciej - xexe (przeplot z trzecim wersem rymowanym wewnętrznie: „nikomu” - „bez domu”, co tylko podkreśla bezrymowość / osamotnienie „imienia Dawida” z pierwszego wersu tej strofy; podobnie wzmacnia je przeczenie inicjujące obydwa te wersy; podtrzymuje te semantykę rym „klęske” - „ciężkie”, rym niedokładny, lecz jednocześnie rym losu: ciążenia ku wyrokowi śmierci - synekdochicznego wobec całej społeczności żydowskiej. W strofie czwartej - fgfg (przeplot współbrzmień dokładnych: „ma” - „złä” i "głowie” - „powiek”, z arcyciekawymi znaczeniami, kolejno: metafizyką i fizyką łza”, bardzo ciekawie powróci P. Ma tyw i e cki w tomie Ta chmura powraca (Kraków 2005).

19 W propagandzie nazistowskiej - z gruntu patriarchalnej - Żyd był przedstawiany jako postać niemęska, sfeminizowana (co miało wydźwięk negatywny, żeńsko-rzeczowy). Często też odwoływano się do niezróżnicowanej kategorii „robactwa”. 
nowej, ponazistowskiej antropologii, przyjętej przez tubylców, niesionej przez anaforę wersów wewnętrznych, interioru - „Bo tu” / „Bo tu”). W strofie piątej - hihi (przeplot w strofie $z$ potrójną, niejako ściętą, anafora „Nie skacz”, dominantą tej całostki; rymy męskie: „Lech” - „śmiech”, i żeńskie: „nie pora” - „na torach”). W strofie szóstej następuje powrót do styczności - j(f)j(f)kk - przedrzeźniającej, po ocalającym akcie mimikry, rym ze strofy czwartej (tam: „ma” - „zła”; tu: „szła” - „łza”, rym, dla oka, anagramowy, dopełniony zapominaniem w męskim rymie: „czas” - „las”). Wreszcie, w strofie siódmej: lltt, rym styczny: „polan” - „wołań” i (paradoksalny) „słyszę” - „ciszę”, na tle dominującego, zagłuszającego łoskotu kół.

Strofy (sfory) z rymami stycznymi okalają te z rymami krzyżowymi, jakby dusza spleciony transport imion. To wszystko przy akompaniamencie nieznośnych powtórzeń, natręctwa anafor i zabójczego stukotu.

\section{Tytuł}

Tytuł jest, być może, kompromisem między niewypowiadalnością bardzo drastycznej diagnozy Szoa, przypominanej po powojennych pogromach, a nawiązaniem do wewnętrznej frazy: „Jeszcze nie pora”, z drugiego wersu piątej strofy. Jeszcze nie pora na samobójstwo? Jeszcze nie pora na próbę ocalenia się na oślep? Kto wyskakiwał z pociągów śmierci, zdawał się na los: strzelano do niego, czasem udawało mu się uciec. (Znana była wstrząsająca historia Stanisława Wygodzkiego, który w wagonie wraz z żoną i córką zażył luminal; one zmarły, a dla niego dawka okazała się zbyt mała - przeżył i tę próbę samobójczą, i pobyt w obozach koncentracyjnych).

\section{Zaduma, poprzedniczka ballady}

Uwięzione w bydlęcych wagonach imiona budzą kilka skojarzeń: są zaledwie domysłem osób (z jednej strony, jak tytułowa, majuskułowa, więc imienna, Dziewczyna $z$ ballady Bolesława Leśmiana i z drugiej - oczywiście - zupełnie inaczej), mają niemożliwe do wyobrażenia desygnaty (to imiona żydowskie, niesłowiańskie) i równocześnie stają się żywą pamięcią o jadących na śmierć; nawiązuja też w tradycji żydowskiej - do miejsca pamięci: Jad wa-Szem oznacza „Miejsce i Imię”20. Szymborska wskazuje „miejsce” (wagony, czarny las ${ }^{21}$ ) i wymienia imiona (osoby).

Widać tu także balladową konwencję, co znakomicie wykazał Głowiński (idąc za stwierdzeniem Czesława Zgorzelskiego, iż balladę cechuje „kunszt wzmiankowania"22):

Ów oryginalny pomysł również wywodzi się $z$ balladowych tradycji. Imiona są tutaj odpowiednikiem występujących w balladach duchów, widm czy upiorów. Skazani na śmierć nie są już w istocie ludźmi,

Tę formułę wykorzystała też J. Ro s za k w książce Miejsce i imię. Niemieckojęzyczni poeci pochodzenia żydowskiego (Warszawa 2014).

21 Warto tu przywołać skojarzenie z przypominającym ów las lasem z ballady J. W. Goethego Król olch, wyrażonym formułą: „Nacht und Wind” („noc i wiatr”), oraz z pokrewnym (choć o proweniencji Wagnerowskiej) nazistowskim kryptonimem akcji deportacyjnej z lat 1941-1942 „Nacht und Nebel” („Noc i Mgła”).

22 Ballada polska. Oprac. Cz. Zg o r zels k i, przy współudz. I. O p a c ki e g o. Wrocław 1962, s. XVII. BN I 177. 
wystawiono ich na najstraszniejsze doświadczenia i upokorzenia, odebrano im wszystko, co ludzkie, stali się zatem jakby tworami jedynymi w swoim rodzaju. Także tutaj mamy do czynienia ze znakomitym sfunkcjonalizowaniem wywodzącego się z ballady ujęcia. Owo zastąpienie osób imionami mówi więcej o Zagładzie niż to, co powiedzieć by można za pośrednictwem bezpośrednich stwierdzeń czy skonwencjonalizowanych obrazów. Tym bardziej że Szymborska nadała imionom umieszczonym w zaplombowanych wagonach najwyższy wymiar symboliczny. Także za sprawą tego, iż imiona łączy z czynnościami ostatnimi, wykonywanymi przez tych, których jedynym przeznaczeniem stało się straszne umieranie w krematoryjnym gazie ${ }^{23}$.

\section{Wiersz, poprzednik wiersza}

Istnieją dwie redakcje owego wiersza, wiersza-opowieści (zasadniczo różniącego się od kunsztownego wiersza-konstrukcji, jakim jest późniejsze Jeszcze). Oba utwory: Transport Żydów oraz Jeszcze, to opowieści o tym samym (o zabijaniu wielu ludzi $z$ premedytacją, w majestacie bezprawia, przy zastosowaniu środków porównywalnych $\mathrm{z}$ torturami ${ }^{24}$ ), a nawet: opowieści te same (jak powiedziałby historyk, traktujący wiersz jak świadectwo), ale - oponowałby literaturoznawca - nie takie same. Szymborska zmienia tytuł w redakcji drugiej Transportu Żydów, właśnie z takiego, który miałby zaświadczać (zawierającego datę $\mathrm{z}$ samego środka Zagłady), na taki, który sygnalizuje odczłowieczenie, uprzedmiotowienie (mówi się wszak o transporcie rzeczy, nie zaś ludzi; w wierszu Jeszcze imiona sytuują się pomiędzy tymi kategoriami, a „transport wołan” to synekdocha reifikująca, ale metaforyczna). Swoistym „refrenem” tego nierymowanego, wolnego wiersza (jego jedyną, przeraźliwa, regularnością) jest osobna wariantywna strofa dystychowa: „Zwyczajem pierwszej nocy pociag / stał długo - wszystkich nie przeczekał” - w której zmienia się jedynie liczebnik. To swego rodzaju przeciwieństwo trzech nocy wiodących ku zmartwychwstaniu, noce $z$ wiersza prowadzą do śmierci, najokrutniej zadanej („przebaczenia nie było nikomu” - to wers domykający całość).

Wiersz wcześniejszy jest też nie taki sam jak Jeszcze, gdyż Szymborska zastosowała w nim partiami lirykę bezpośrednią - rozmowy wewnątrz wagonów: w drugiej całostce poprzez, intymny i deziluzyjny jednocześnie, zwrot dziecka do ojca; w kolejnej - dialog między mężem a żoną; w następnej - dramatyczne słowa skierowane do małego dziecka.

Utwór skonstruowano zresztą misternie (Głowiński dostrzega w nim ślady lektury poezji Juliana Przybosia, jej rytmiki i stylistyki ${ }^{25}$ ): pierwsza i ostatnia całostka mają charakter reportażowy (narracja trzecioosobowa $z$ lekkim podwyższeniem stylu poprzez inwersje i dobór leksyki), a pomiędzy nimi następuje przeplot dystychów-refrenów (strof parzystych: drugiej, czwartej, szóstej) ze strofami nieparzystymi (dialogowymi) - trzecią, piątą, siódmą.

Głowińs ki, op. cit., s. 353.

Wierszem W. Szy m bor s ki ej Tortury z tomu Ludzie na moście (1986) zajęłam się w osobnym tekście (K. Ku czy ń s ka - Ko s c h a ny, „Życie - jedyny sposób / żeby (...) // odróżniać ból / od wszystkiego, co nim nie jest”. Próba czytania wierszy „Tortury”, „Rozpoczęta opowieść”, „Identyfikacja”. W zb.: Niepojęty przypadek, s. 345-358).

Głowińs ki, op. cit., s. 348. 
TRANSPORT ŻYDÓW $1943^{26}$

Na zewnątrz jest świat cały: dal nasycona lasem, wzgórza u źródeł pojone i śmierć pod pełnią powietrza. Lecz im - zamknięci w rozpęd szyn zmieciono twarze w ciasną ciemność. Krzyk zamilkł na bezdźwięczny ołów: świadectwo głębokości ziemi.

Zwyczajem pierwszej nocy pociag stał długo - wszystkich nie przeczekał.

- Uczyłeś mnie świtu życia z książek, owadów i liści.

Dziś, ojcze, do pięści twoich przysycha krew nienawiści -

Zwyczajem drugiej nocy pociagg stał długo - wszystkich nie przeczekał.

- Po co nam płacz niewidzialny, żono, na zawsze żono.

Łzy są kradzieżą oddechu, ciała cięższe od zgonu -

Zwyczajem trzeciej nocy pociąg stał długo - wszystkich nie przeczekał.

- Synu maleńki, szparą w desce nakarmię twoje usta, abyś o jedno tchnienie przeżył ręce me puste.

O przyjściu czwartej nocy człowiek wyważył opór wagonu.

Pierś miał podarta - w piersi przebaczenia nie było nikomu.

\section{TRANSPORT ŻYDÓW ${ }^{27}$}

Na zewnątrz jest świat cały: dal nasycona lasem, wzgórza u źródeł pojone i śmierć pod pełnią powietrza. Lecz im (- zamknięci w rozpęd szyn -) zmieniono twarze w ciasną ciemność. Krzyk zamilkł na bezdźwięczny ołów. Świadectwo głębokości ziemi.

Zwyczajem pierwszej nocy pociag stał długo - wszystkich nie przeczekał. z 25 IV - 1 V, s. 2.

27 Na podstawie: W. Szy m b or s k a, Czarna piosenka. Kraków 2014, s. 68-69. 


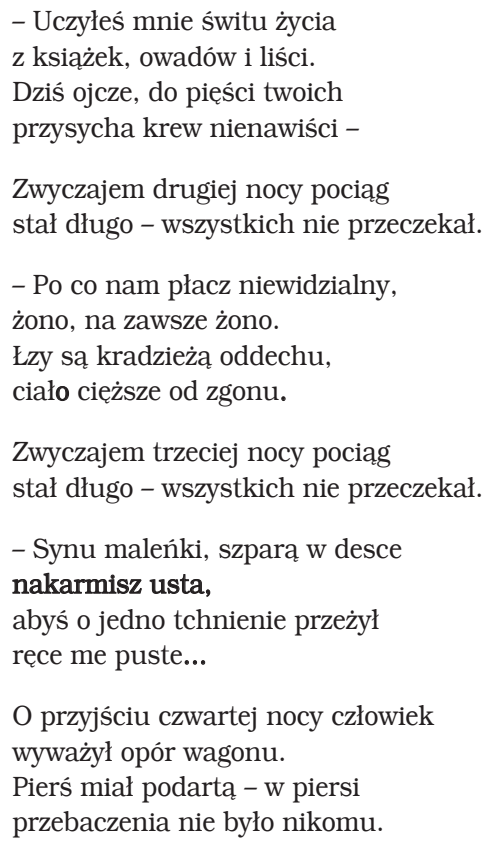

\section{Przed Zagłada, po Zagładzie}

Głowiński napomknął, iż jeden wiersz wykluwa się z drugiego. Warto pójść tropem tej myśli, by zobaczyć uparta pracę poetki nad materią najtrudniejszą, pracę, dzięki której odsłania się droga ku synekdochom otwierającym czytelniczą wrażliwość i wyobraźnię (o czym napomknął Balcerzan). Cieślak przypomniał, że za wielkimi wierszami stoją inne wielkie wiersze i że te powinowactwa bywają - z wolnego wyboru poetów, może czasem $\mathrm{z}$ powodu rytmu, słyszanego $\mathrm{w}$ ich uchu - przedziwne, przeczą oczywistościom. Tak za wierszami Szymborskiej o Zagładzie stoi Lokomotywa Tuwima.

Wszyscy - myślę o nas, filologach - znamy receptę twórczej lektury, wypisaną przez Kazimierza Bartoszyńskiego, zachętę do czytania wielokrotnego, wielokontekstowego. Gdy dzieje się tak, że po wiersze arcydzielne (także arcy-dzielne) sięga wielokrotnie wielu $\mathrm{z}$ nas, wyłania się $\mathrm{z}$ tych lektur, nakładajacych się na siebie, a często nie wiedzacych o sobie nawzajem, jeszcze wyraźniejszy obraz niebagatelnego poetyckiego warsztatu (laboratorium) twórczego, który w przypadku najlepszych dzieł narusza dotychczasowa granicę tego, co pochopnie nazywa się nieprzedstawialnością.

Jednocześnie lektura wielokrotna i porównawcza pozwala zobaczyć Wisławę Szymborska jako poetkę autoemendacyjna i jako poetkę dwu dyskursów: tego, który ledwie unosi doświadczenie Zagłady Żydów, i tego, który (podobnie jak najlepsze wiersze na ten temat ${ }^{28}$ ) dotyka sedna owego szczególnego ludobójstwa, ce-

28 Mam tu na myśli wiersze: Cz. Miło s za Campo di Fiori i Biedny chrześcijanin patrzy na getto, T. Różewicza Ocalony, W. Broniewskiego „Ballady iromanse”, M. Białoszewskiego 
zury w dziejach ludzkości, wyznaczającej nowy punkt odniesienia na osi czasu: przed Zagłada i po Zagładzie (jak przedtem liczono: przed Chrystusem i po Chrystusie). Szymborska przepoczwarza poetykę - od reportażu ku wielkiej metaforze, od pisania o świadkowaniu samej Zagładzie (Transport Żydów 1943) do przedstawienia sytuacji po pogromie kieleckim, po kolejnym żydowskim exodusie, z gorzka ironią nawołujaccego do mimikry spowodowanej przez polski antysemityzm w wierszu Jeszcze:

\author{
Syn niech imię słowiańskie ma, \\ bo tu liczą włosy na głowie, \\ bo tu dziela dobro od zła \\ wedle imion i kroju powiek. \\ Nie skacz w biegu. Syn będzie Lech.
}

Przypomina się w tym miejscu rozważań formuła tytułowa tomu poetyckiego Eugeniusza Tkaczyszyna-Dyckiego: „Imię i znamię”, a także poruszający wiersz Piotra Matywieckiego o incipicie „Wielu Żydów o wojnie zmieniało nazwiska...” (z tomu Widownia z 2012 roku).

Doświadczenie Zagłady ukształtowało najistotniejszych polskich twórców. Ich poetyka wykluła się „na łące popiołów” 29: w zmaganiu z tym, co trudne do unaocznienia, co oscyluje na granicy takiej możliwości, co wymaga najwyższego poetyckiego kunsztu i zarazem zawieszenia tego kunsztu, a także największej wrażliwości (mimo iż wystawiono ją na zniszczenie). Dwa przywołane wiersze Szymborskiej, ich tematyczna przyległość i odmienność poetyki pokazują - by tak rzec, w synekdochicznym skrócie - tę ogólną prawidłowość (i szczególną drogę autorki - jednocześnie). Maestria, groza.

\author{
Abstract \\ KATARZYNA KUCZYŃSKA-KOSCHANY Adam Mickiewicz University, Poznań \\ ORCID: 0000-0002-1671-2278
}

"JESZCZE" ("STILL") ONE MORE NOTE TO WISŁAWA SZYMBORSKA'S POEM

The article assumes a reinterpretation of Wisława Szymborska's poem Jeszcze (Still) in reference it its previous readings. The poem is here also confronted with other piece by the Polish Nobel Prize winner entitled Transport Żydów 1943 (Transport of Jews 1943). Variants of both texts are taken into consideration in the paper. The new interpretive proposal is closely linked with a philological analysis of text, and also includes references to the present-day state of art in the Shoah. The poetics of the article is intentionally ascetic and by-textual since the author follows the paths of superb predecessors, adding merely another note to Szymborska's poetic masterpiece. The analysis also includes the poem's title, its literary genetic context, the transformation of the poetess' own idiom, and the piece's intellectual potential. In a few places the paper suggests interpretive transaccentuation, i.e. shift of stresses as a consequence resulting from the state of art in the poem.

Moja głowa była Żydem, J. Fi cow ski e go Odczytanie popiołów i Z. Gin czanki Non omnis moriar.

29 Formułę tę czerpię z tytułu pracy B. Engelking (Na łące popiołów. Warszawa 1993). 